\title{
A longitudinal analysis on interruption in preschool children who stutter during interactions with their mothers*
}

\author{
Hyo-Jung Kwak ${ }^{1} \cdot$ Si-Hyeon Hwang ${ }^{1} \cdot$ Pu-Reum Song ${ }^{2} \cdot$ Hyun-Sub Sim ${ }^{1} \cdot$ Soo-Bok Lee ${ }^{2, * *}$ \\ ${ }^{1}$ Department of Communication Disorders, Ewha Womans University, Seoul, Korea \\ ${ }^{2}$ Department of Speech Language Therapy and Aural Rehabilitation, Woosong University, Daejeon, Korea
}

\begin{abstract}
The purpose of this study was to investigate, longitudinally, interruption behavior which children who do stutter (CWS), children who do not stutter (CWNS) and their mothers and relationship with disfluency of children showed during interactions with their mothers. Subjects for this study consisted of 2-5 year old CWS (male 2 and female 4), an age-matched group of CWNS (male 3 and female 3), and their mothers. Frequencies of normal disfluency (ND) and abnormal disfluency (AD) in children group and frequency of interruption and simultalk duration in children and mothers group were measured two times (initial visit and 12 months later) over the course of one year. As a result, no significant difference was observed in frequency of interruption and simultalk duration both between two mother groups and between two child groups at initial visit and 12 months later. However, frequency of interruption increased significantly over the course of one year in CWS group. A significant group difference was found in frequency of interruption of mothers but, no significant difference was observed in simultalk duration of mothers at initial visit. In the CWS - mothers group, no factors were related with disfluency of children at initial visit and 12 months later. These findings suggest that interruption is not just negative behavior, and that reducing interruption should be considered in child $\cdot$ parent interaction therapy for CWS.
\end{abstract}

Keywords: preschool children, stuttering, longitudinal study, interaction, interruption, simultalk duration

\section{1. 서론}

대화는 두 사람 이상의 대화 참여자가 공통의 화제로 말을 주 고받는 쌍방향적 의사소통 과정으로(Heo \& Lee, 2012), 대화 참 여자들의 화자와 청자 역할이 바뀌면서 순차적으로 대화차례 (turn)가 일어나게 되고 대화차례를 주고받게(turn-taking) 된다. 이때 화자는 적절한 길이의 대화차례를 유지해야 하며 청자는 화자의 말을 방해하지 않는 기술이 필요하다(Park \& Choi, 2019).

대화 내에서 대화 참여자들이 대화차례를 가지거나 대화차

\footnotetext{
* This work was supported by the Ministry of Education of the Republic of Korea and National Research Foundation of Korea (NRF-2018S1A5A2A 03036976).

** sblee@wsu.ac.kr, Corresponding author

Received 10 November 2021; Revised 12 December 2021; Accepted 12 December 2021

(C) Copyright 2021 Korean Society of Speech Sciences. This is an Open-Access article distributed under the terms of the Creative Commons Attribution NonCommercial License (http://creativecommons.org/licenses/by-nc/4.0) which permits unrestricted non-commercial use, distribution, and reproduction in any medium, provided the original work is properly cited.
} 
례를 주고받게 되는 타이밍은 말속도, 대화차례 쉼 시간(turnswitching pause), 끼어들기(interruption) 빈도 및 끼어들기 시 동 시에 말한 시간(simultalk duration) 등과 같은 시간적(temporal) 요인들에 의해 조절될 수 있다(Zebrowski, 1995). 그러나 대화 참 여자들은 대화 상대방의 대화차례 빈도, 길이 및 내용을 정확하 게 예측하기 어려우며(Sacks et al., 1974), 화자의 경우 본인의 대화차례를 구체적으로 계획하지 못한 상태에서 참여하기 때 문에 독백(monologue) 상황보다 더 많은 요구(demand)가 주어 지게 된다(Weiss, 1995). 이에 능숙하게 대화를 하기 위해서는 대화 상대방에 의해 나타나는 많은 변수들을 빠르게 조절할 준 비가 되어 있어야 한다(Weiss, 2004).

그러나 신경학적, 생리학적, 정서적, 그리고 언어학적으로 성 숙되어 가는 과정에 있는 학령전 아동은 대화 상황에서 주어지 는 요구를 적절히 처리하는데 더 취약할 수 있다. 따라서 아동 과 부모가 언어적 상호작용(verbal interaction)을 할 때 부모의 빈 번한 끼어들기, 빠른 말속도, 짧은 대화차례 쉼 시간 같은 시간 적 요인들은 아동이 본인의 대화차례 내용과 형식을 계획하고 수행하는데 있어 의사소통 시간 압박(communication pressure) 을 느끼게 하는 요소(Kelly, 1993; Zebrowski et al., 1996)로 작용 할 수 있다. 아동은 이러한 압박을 느낀 경우, 압박에 대응하는 의사소통 전략들을 수립하지만 이러한 전략들이 아동이 발화 를 계획하고 산출하는 용량(capacity)을 넘는 경우 말더듬 발생 및 악화를 초래할 수 있다(Conture, 1990; Savelkoul et al., 2007). 특히 말더듬아동은 유창성을 저해하는 자극에 일반아동보다 더 많은 영향을 받기 때문에(Min, 2007) 의사소통 시간 압박은 말더듬 발생 및 지속에 중요한 역할을 하는 것으로 간주되어 왔 다(Starkweather \& Gottwald, 1990).

의사소통 시간 압박 요소 중, 끼어들기는 아동의 유창성에 영 향을 미치는 잠재적 요인으로 간주되어 왔다(Kasprisin-Burrelli et al., 1972; Mordecai, 1979). 끼어들기는 ‘화자가 본인의 대화차 례에서 발화를 마무리하기 전에 대화 상대방인 청자가 질문이 나 발언으로 화자의 대화차례 지속성(continuity)을 끊는 것'을 의미하는데(Meyers \& Freeman, 1985), 부모가 아동의 대화차례 에 끼어들 시 아동 또한 본인의 대화차례를 얻기 위해 끼어들기 를 보일 수 있고(Zebrowski \& Kelly, 2002), 그 과정에서 아동의 말 유창성이 방해를 받기 때문에 오랫동안 부모의 부정적인 특 성으로 인식되어 왔다(Egolf et al., 1972; Van Riper, 1982). 이에 부모의 끼어들기는 아동의 비유창성과 관련이 있는 것으로 간 주되며 임상 현장에서 부모교육과 간접치료 시 부모의 시간적 요인을 조절하도록 권고하고 있다.

그러나 선행연구들은 연구 결과에 따라 끼어들기를 부정적 인 특성이 아닌 긍정적으로 해석하거나(Kelly \& Conture, 1992; Meyers \& Freeman, 1985), 대상 아동들의 말더듬 중증도, 생활연 령, 연구 형태(특성 연구, 중재 연구) 등과 같은 조건이 동일하지 않아 연구 결과가 일관적이지 않은 실정이다.

끼어들기에 대한 선행연구들은 말더듬아동 - 부모 집단과 일 반아동 - 부모 집단 간 비교를 통해 끼어들기 특성 차이가 있는 지 살펴보거나 끼어들기 특성과 아동의 비유창성 간의 관계를
살펴보았다. 끼어들기 특성으로 끼어들기 빈도나 끼어들기 시 동시에 말한 시간을 측정하는데, 끼어들기 시 동시에 말한 시간 은 끼어들기가 나타났을 때, 화자와 청자의 발화가 중첩되는 시 간을 의미한다(Kelly, 1994; Kelly \& Conture, 1992).

Kasprisin-Burrelli et al.(1972)은 학령기 말더듬 및 일반아동과 각 아동의 부모(어머니 또는 아버지)를 대상으로 부모 끼어들기 빈도를 분석하여 그룹 간 차이를 비교하였을 때, 말더듬아동 부 모가 일반아동 부모보다 유의하게 높은 끼어들기 빈도를 보였 다고 하였다. Mordecai(1979)는 학령전 말더듬 및 일반아동과 각 아동의 부모(어머니와 아버지)를 대상으로 부모 끼어들기 빈 도를 분석하여 그룹 간 차이를 비교하였다. 연구 결과, 말더듬 아동 부모가 일반아동 부모보다 유의하게 높은 끼어들기빈도 를 보였으며 연구자들은 이러한 연구 결과를 아동의 의사소통 노력에 대한 부모의 관심이 부족하여 아동의 발화를 방해하는 부정적인 상호작용의 증거로 해석하였다.

반면 Meyers \& Freeman(1985)은 학령전 말더듬 및 일반아동 과 각 아동의 어머니를 대상으로 어머니 끼어들기 빈도를 분석 하여 그룹 간 차이를 비교한 결과, 집단 간 끼어들기 빈도에 유 의한 차이가 없었으나, 두 어머니 그룹 모두 아동의 유창한 말 보다 비유창한 말에 더 많이 끼어들었다고 하였다. 이러한 연구 결과에 대해 연구자들은 아동의 비유창성이 부모에게 아동이 본인의 대화차례를 마무리하지 않고 포기하는 신호로 인식됨 과 동시에 적절한 단어를 찾거나 생각을 표현하는데 어려움이 있다는 신호로 해석될 수 있으며, 이로 인해 부모는 아동에게 도움을 주기 위해, 즉 긍정적인 상호작용의 증거로 아동의 발화 에 끼어들었을 수 있다는 가능성을 제시하였다.

Kelly \& Conture(1992)는 말더듬 및 일반아동과 아동의 어머 니를 대상으로 아동과 부모의 끼어들기 빈도와 함께 끼어들기 시 동시에 말한 시간을 분석하여 그룹 간 차이를 비교하고, 각 집단에서 아동 및 부모의 끼어들기 특성과 아동의 비유창성 간 의 상관관계를 살펴보았다. 연구 결과, 말더듬아동 집단과 일반 아동 집단 간 그리고 말더듬아동 어머니 집단과 일반아동 어머 니 집단 간 유의한 차이가 없었으며, 아동 및 부모의 끼어들기 특 성과 아동의 비유창성 간의 유의한 상관관계가 나타나지 않았다 고 보고하였다. 그러나 아동의 SSI(stuttering severity instrument; Riley, 1980) 점수와 어머니의 끼어들기 시 동시에 말한 시간 사 이에 강한 정적상관관계가 나타났는데, 이는 아동의 말더듬 중 증도가 심할수록 아동과 어머니가 끼어들기 시 동시에 말한 시 간이 길다는 것을 의미한다. 즉, 아동의 비유창성에 의해 부모 의 끼어들기 행동이 영향을 받거나 또는 부모의 끼어들기 행동 이 아동의 비유창성에 영향을 미친 것으로 볼 수 있으며, 연구 자들은 부모가 아동의 발화에 끼어들어 동시에 말한 이유를 Meyers \& Freeman(1985) 연구와 비슷한 맥락으로 아동이 본인 의 대화차례를 마무리할 때 겪는 어려움을 줄여 주기 위함이라 고 하였다.

또한 부모뿐만 아니라 아동이 본인의 대화차례를 얻기 위해 끼어들기를 보일 수 있다(Zebrowski \& Kelly, 2002)는 주장도 있 다. 하지만 대화 기술은 매우 어린 연령부터 발달하므로 어린 
아동들이 대화 상대방의 대화차례에 끼어들기보다는 침묵 (silent) 상태를 유지한다(Garvey \& Berninger, 1981; Kelly \& Conture, 1992)는 주장도 있어 아동의 끼어들기 특성 또한 명확 하게 밝혀지지 않은 실정이다.

이에 부모뿐만 아니라 아동의 끼어들기 특성도 함께 분석하 고, 집단 간 차이뿐만 아니라 아동의 비유창성과 끼어들기 특성 간의 상관관계를 살펴볼 필요가 있다. 국외뿐만 아니라 국내에 서도 다른 시간적 요인에 비해 끼어들기 특성에 관한 연구는 거 의 없는 실정이다. 따라서 근거에 기반한 중재를 하기 위해서는 부모와 아동의 시간적 특성과 아동의 비유창성 간의 관계를 정 확하게 파악할 필요가 있다.

더불어 말더듬 발생 및 지속과 관련 있는 아동의 환경적 요인 과 유전적, 신체적 요인들은 상호작용하여 아동의 말더듬에 영 향을 미치며, 요인들 간의 상호 영향력 정도는 아동의 발달과정 에 따라 변화하므로(Smith \& Kelly, 1997), 일회성이 아닌 종단 적 분석을 통해 말더듬의 발달과 여러 요인들과의 관련성을 살 펴볼 필요가 있다(Kwak et al., 2021; Lee \& Sim, 2015, Lee \& Sim, 2016; Lee et al., 2019).

Kwak et al.(2020)은 학령전 말더듬 및 일반아동과 각 아동의 어머니가 놀이를 통한 상호작용 상황에서 산출한 발화를 6 개월 간격으로 6 개월 동안 총 두 차례 수집하여 아동과 어머니 끼어 들기 빈도를 분석하였다. 연구 결과, 평가 시점과 평가 후 6개월 시점에서 말더듬아동 집단과 일반아동 집단 간 그리고 말더듬 아동 어머니 집단과 일반아동 어머니 집단 간 끼어들기 빈도에 유의한 차이가 없었으며, 아동 및 부모의 끼어들기 빈도와 아동 의 정상적 비유창성(normal disfluency, ND) 및 비정상적 비유창 성(abnormal disfluency, $\mathrm{AD}$ ) 간의 유의한 상관관계가 나타나지 않았다.

본 연구에서는 학령전 말더듬아동과 어머니가 놀이를 통한 상호작용 상황에서 산출한 발화를 1 년 간격으로 12 개월 간 총 두 차례 수집하여 아동과 부모의 끼어들기 행동을 살펴보았다. 말을 더듬은 후 1년 이내에 자연회복이 많이 나타나므로 평가 시점과 평가 후 12 개월 시점에 살펴보았다. 또한 끼어들기 빈도 뿐만 아니라 끼어들기 시 동시에 말한 시간을 함께 살펴보고자 하며, 아동과 부모의 끼어들기 행동이 아동의 비유창성과 관련 성이 있는지, 그리고 말더듬아동과 어머니의 상호작용 특성이 일반아동 집단과 비교했을 때 차이를 보이는지 종단적으로 살 펴보았다.

연구문제는 다음과 같다:

(1) 집단(말더듬아동, 일반아동) 및 시점(평가 시점, 평가 후 12 개월 시점)에 따른 아동의 비유창성 $(\mathrm{ND}, \mathrm{AD})$ 빈도에 유의한 차이가 있는가?

(2) 집단(말더듬아동- 어머니, 일반아동 - 어머니) 및 시점 (평가 시점, 평가 후 12 개월 시점)에 따른 끼어들기 특성 (끼어들기 빈도, 끼어들기 시 동시에 말한 시간)에 유의한 차이가 있는가?

(3) 말더듬아동 - 어머니 집단의 시점별(평가 시점, 평가 후 12 개월 시점) 아동의 비유창성 빈도와 아동과 부모의 끼
어들기 특성 간 유의한 상관이 있는가?

\section{2. 연구 방법}

\section{1. 연구대상}

본 연구는 초기 말 - 언어평가 시 만 2-5세 말더듬아동 6명(남 자: 2 명, 여자: 4명)과 아동의 어머니 6명, 일반아동 6명(남자: 3 명, 여자: 3 명)과 아동의 어머니 6 명, 총 12 쌍을 대상으로 하였 다. 각 집단의 어머니들은 본 연구에 대한 상세한 안내를 충분 히 듣고 서면으로 연구 참여에 동의하였다. 본 연구는 우송대학 교 기관생명연구윤리심의위원회(IRB)의 승인을 받아 진행되었 다(1041549-210413-SB-120).

대상자 선정 기준은 다음과 같다. 말더듬아동은 (1) 부모 또는 보건복지부 언어재활사 자격증을 소지한 언어재활사에 의해 말 더듬으로 평가되었으며, (2) 파라다이스-유창성검사 II(ParadiseFluency Assessment II, P-FA II; Sim et al., 2010) 결과, 말더듬 중증 도가 약함이거나 중간이었고, (3) 『수용·표현어휘력검사(Receptive \& Expressive Vocabulary Test, REVT; Kim et al., 2009)』실시 결과, 백분위 점수가 -1 표준편차 이상에 속하며, (4)『우리말 조 음 - 음운검사(Urimal Test of Articulation an Phonology, U-TAP; Kim \& Shin, 2004)』실시 결과, 낱말수준에서의 자음정확도가 정상범위에 속하고, (5) 기타 동반장애가 없는 아동을 대상으로 하였다. 연구윤리에 따라 말더듬 치료 여부는 말더듬아동 대상 자 선정 기준에 포함하지 못하였고, 본 연구에 선정된 대상 아 동 중, 2 명은 평가 후 연구기간 동안 간접치료와 직접치료를 1 년 동안 받았고, 3 명은 간접치료를 3 개월 동안 받았으며, 1 명은 치료를 받지 않았다.

일반아동은 말더듬아동과 생활연령 및 언어연령이 일치하는 아동으로 선정하였다. (1) 부모가 말더듬 문제가 없는 것으로 보 고하며, (2) P-FA II 결과, 말더듬 중증도가 약함으로 나타났고, (3) REVT 실시 결과, 백분위 점수가 -1 표준편차 이상에 속하 며, (4) U-TAP 실시 결과, 낱말수준에서의 자음정확도가 정상범 위에 속하고, (5) 기타 동반장애가 없는 아동을 대상으로 하였 다. 연구 참여 아동들에 대한 구체적인 정보는 부록 1 과 같다.

집단 간 동일성 검정을 위한 맨-휘트니 U-검정(Mann-Whitney U-test) 비모수 검정 결과, 생활연령, REVT 수용 및 표현어휘점 수, U-TAP 낱말수준에서의 자음정확도에서 집단 간에 통계적 으로 유의한 차이를 보이지 않았다( $p>.05)$.

\section{2. 연구 절차}

대상자 선정 기준을 충족한 말더듬아동 - 어머니, 일반아 동 - 어머니들을 대상으로 연구자가 아동의 가정 또는 어린이 집/유치원에 방문하여 아동과 어머니에게 약 20-30분 동안 상 호작용 놀이를 진행하게 하여 총 두 차례(평가 시점, 평가 후 12 개월 시점) 아동과 어머니의 발화를 녹화 수집하였다.

상호작용 놀이는 조용한 방에서 진행되었으며, 아동이 평소 에 가지고 노는 ‘찰훍놀이', ‘블록놀이' 등의 장난감을 활용하 고, 자연스러운 놀이 상황이 되도록 하기 위해 어머니에게 ‘평 
소와 같이 아동과 대화하고 놀아주세요'라는 최소한의 지시만 주고 진행하게 하였다.

\section{3. 자료 분석}

\subsection{1. 발화 구분 및 선택}

상호작용 놀이를 통해 수집된 발화 자료 중, 아동의 첫 5 발화 를 제외하고 순서대로 100 발화와 아동의 100 발화에 포함된 어 머니의 발화를 전사하였다. 각 집단별 발화에서 나타난 평균 음 절수는 말더듬아동 집단의 경우 1차 596음절 $( \pm 104.61), 2$ 차 773 음절 $( \pm 214.60)$ 로 나타났고, 말더듬아동 어머니 집단의 경우, 1 차 699음절 $( \pm 291.99), 2$ 차 664음절 $( \pm 506.73)$ 로 나타났다. 일반아 동 집단의 경우, 1 차 609 음절 $( \pm 122.89), 2$ 차 667 음절 $( \pm 131.29)$ 로 나타났고, 일반아동 어머니 집단의 경우, 1 차 1,126 음절 $( \pm 249.22)$, 2차 609음절 $( \pm 461.41)$ 로 나타났다. 그리고 Kwak et al.(2021)의 분 석 기준을 참고로 하여 발화를 구분 및 선택하였다.

\subsection{2. 아동의 비유창성(ND, $\mathrm{AD})$ 빈도 분석}

아동의 100 발화에 포함된 $\mathrm{ND}$ 와 $\mathrm{AD}$ 빈도를 분석하였다. $\mathrm{ND}$ 와 $\mathrm{AD}$ 유형은 P-FA II의 비유창성 분류 기준에 따라 측정하였 다. 만약 한 단어에서 두 개의 $\mathrm{ND}$ 또는 $\mathrm{AD}$ 유형이 동반되어 나 타나는 경우(예: 막힘을 동반한 반복2)는 2개의 ND 또는 $\mathrm{AD}$ 유 형으로 계산하였다(Ambrose \& Yairi, 1999).

\subsection{3. 아동과 어머니의 끼어들기 빈도 및 끼어들기 시 동시에 말한 시간 분석}

아동의 100 발화와 아동의 100 발화에 포함된 어머니의 발화 에서 나타난 아동과 어머니의 끼어들기 빈도와 끼어들기 시 동 시에 말한 시간을 측정하기 위하여 각 아동 - 어머니의 상호작 용 영상을 Goldwave 5.70(Craig, 2013)을 사용하여 .wav 형식의 오디오 파일로 변환하였다(sampling rate: $44 \mathrm{kHz}, \mathrm{mono}$ ). 그리고 Praat 5.4.18(Boersma \& Weenink, 2012)을 사용하여 빈도 및 시간 을 측정하였다.

\subsubsection{1. 끼어들기 빈도 분석}

아동의 끼어들기는 화자인 어머니가 발화를 하는 중에 청자 인 아동이 끼어든 경우를, 어머니의 끼어들기는 화자인 아동이 발화를 하는 중에 청자인 부모가 끼어든 경우를 의미한다(Kelly \& Conture, 1992). 끼어들기 유형을 아동의 끼어들기와 어머니 의 끼어들기로 분류한 후, 아동의 100 발화에서 나타난 아동과 어머니의 끼어들기 빈도를 분석하였다. 만약 한 발화에서 끼어 들기가 2회 나타난 경우(예: 화자인 아동이 발화를 하는 중에 청 자인 어머니가 끼어들어 발화하고, 이후 다시 화자가 어머니로 바뀐 발화에서 청자인 아동이 끼어들어 발화한 경우), 아동의 끼어들기 1 회, 어머니의 끼어들기 1 회로 각각 계산하였다.

또한, (1) Kwak et al.(2021)의 분석 기준을 참고하여 선택한 발화와 선택하지 않은 발화가 중첩되는 경우, (2) 아동과 어머니 가 동시에 발화를 시작(simultaneous start)하여 대화 방해자가 존
재하지 않는 경우(Livingston et al., 2000), (3) 아동과 어머니가 동시에 발화를 시작하였는지, 끼어들기 시 동시에 발화를 시작 하였는지 구분할 수 없는 경우, 끼어들기에서 제외하였다.

아동의 끼어들기 빈도는 100 발화에서 나타난 총 끼어들기 빈 도 즉 비율 $(\%)$ 을 구하였고, 어머니의 끼어들기 빈도는 아동의 100 발화에서 나타난 어머니의 발화양에 따라 결과가 달라질 수 있으므로 아동과 마찬가지로 100 발화에서 나타난 끼어들기 빈 도 즉 비율 $(\%)$ 을 구하였다.

\subsubsection{2. 끼어들기 시 동시에 말한 시간의 평균 분석}

끼어들기 빈도 분석 기준에 따라 아동 혹은 어머니의 끼어들 기로 간주된 발화에 대해 끼어들기 시 동시에 말한 시간을 분석 하였다. 아동의 끼어들기 시 동시에 말한 시간은 아동의 끼어들 기 시, 아동과 어머니의 발화 중첩이 시작되는 지점부터 끝나는 지점까지의 지속시간을, 어머니의 끼어들기 시 동시에 말한 시 간은 어머니의 끼어들기 시, 어머니와 아동의 발화 중첩이 시작 되는 지점부터 끝나는 지점까지의 지속시간을 측정하였다 (Kelly \& Conture, 1992)(그림 1). 이후 아동 혹은 어머니의 끼어 들기 시 동시에 말한 시간의 총합을 끼어들기 빈도로 나누어 끼 어들기 시 동시에 말한 시간의 평균을 계산하였다.

끼어들기 시 동시에 말한시간의 평균 $(\mathrm{sec})=\frac{\text { 끼어들기 시동시에 말한시간의총합 }}{\text { 끼어들기빈도 }}(1)$

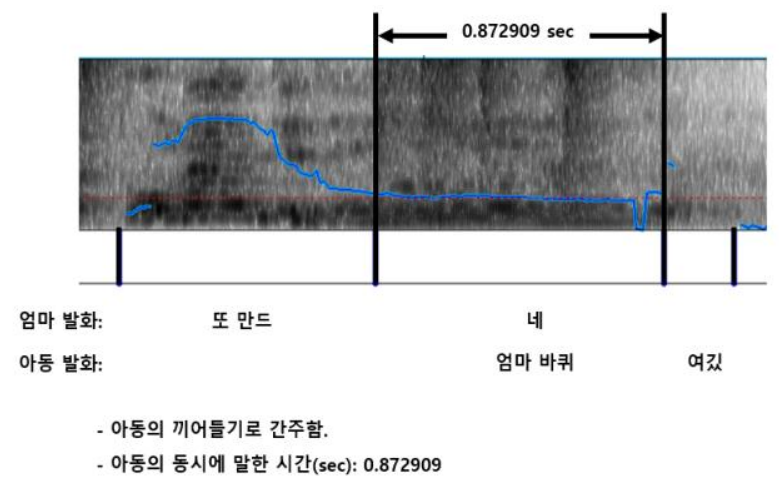

그림 1. 아동 끼어들기 시 동시에 말한 시간 측정 방법

Figure 1. Simultalk duration calculation: child interruption

2.4. 평가자 간 신뢰도

본 연구의 종속변수인 비유창성 $(\mathrm{ND}, \mathrm{AD})$ 빈도와 끼어들기 특성(끼어들기 빈도, 끼어들기 시 동시에 말한 시간)의 평가자 간 신뢰도를 측정하기 위하여 전체 자료의 $20 \%$ 에 해당하는 4 명 [CWS(children who do stutter) 2명, CWNS(children who do not stutter) 2 명]을 임의적으로 선정하였다. 그리고 연구자와 연구자 에게 분석 기준에 대한 훈련을 받은 2 급 언어재활사 2 인이 독립 적으로 종속변수를 분석하였다.

비유창성 빈도의 일치율은 평가자 간 분석 결과, $\mathrm{ND}$ 와 $\mathrm{AD}$ 유 형이 동일한 비율을 말하고, 끼어들기 빈도의 일치율은 평가자 간 분석 결과, 끼어들기 위치가 동일한 비율을 말하며, 그리고 
끼어들기 동시에 말한 시간의 일치율은 소수점 첫째자리에서 반올림하였을 때 정수값이 동일한 비율을 말한다. 각 일치율은 아래와 같은 공식으로 산출하였다.

$$
\text { 비유창성 빈도일치율 }(\%)=\left(\frac{\text { 일치한 } N D \text { 유형 빈도 }}{\text { 발화에서 나타난 } N D \text { 유형 빈도 }}\right) \times 100
$$

아동의 $\mathrm{ND}$ 빈도, $\mathrm{AD}$ 빈도, 끼어들기 빈도, 끼어들기 시 동시 에 말한 시간은 각각 $75.6 \%, 80.4 \%, 85.7 \%, 83.3 \%$, 어머니의 끼 어들기 빈도, 끼어들기 시 동시에 말한 시간은 각각 $71.4 \%$, $83.3 \%$ 였다.

\section{5. 통계처리}

본 연구에서는 IBM SPSS statistics 26.0(IBM-SPSS, Chicago, II, USA)을 이용하여 자료를 분석하였다. 첫째, 각 시점(평가 시 점, 평가 후 12 개월 시점)에서 말더듬아동 집단과 일반아동 집 단 간 $\mathrm{ND}$ 와 $\mathrm{AD}$ 빈도, 끼어들기 빈도, 끼어들기 시 동시에 말한 시간이 유의한 차이가 있는지, 말더듬아동 어머니 집단과 일반 아동 어머니 집단 간 어머니의 끼어들기 빈도, 끼어들기 시 동 시에 말한 시간이 유의한 차이가 있는지 살펴보기 위하여 맨-휘 트니 U-검정(Mann-Whitney U-test)을 실시하였다. 둘째, 각 집단 (말더듬아동 집단, 일반아동 집단, 말더듬아동 어머니 집단, 일 반아동 어머니 집단)에서 시점(평가 시점, 평가 후 12 개월 시점) 간 차이가 있는지 살펴보기 위하여 윌콕슨 부호-순위 검증 (Wilcoxon Signed-Rank Test)을 실시하였다. 셋째 각 시점 및 각 집단(말더듬아동 - 어머니 집단, 일반아동 어머니 집단)에서 요 인 간 상관관계를 살펴보기 위하여 스피어만 등위상관분석 (Spearman rank correlation)을 실시하였다.

\section{3. 연구 결과}

\section{1. 아동의 비유창성 빈도}

각 시점(평가 시점, 평가 후 12 개월 시점)에서 말더듬아동 집 단과 일반아동 집단의 $\mathrm{ND}$ 및 $\mathrm{AD}$ 빈도에 대해 비교한 결과는 표 1 과 같다.

\subsection{1. 집단 간 비유창성 빈도 비교}

각 시점에서 집단 간 $\mathrm{ND}$ 및 $\mathrm{AD}$ 빈도에 유의한 차이가 있는가 를 알아보기 위해 Mann-Whitney U-Test를 실시한 결과, 평가 시 점에서 말더듬아동 집단의 $\mathrm{ND}$ 및 $\mathrm{AD}$ 빈도가 일반아동 집단의 $\mathrm{ND}$ 및 $\mathrm{AD}$ 빈도보다 통계적으로 유의하게 높은 것으로 나타났 다(ND 빈도: $Z=-2.1, p<.05 ; \mathrm{AD}$ 빈도: $Z=-2.892, p<.01)$.

반면, 평가 후 12 개월 시점에서는 두 집단 모두 유의한 차이 가 없는 것으로 나타났다(ND 빈도: $Z=-1.363, p=173 ; \mathrm{AD}$ 빈도: $Z=-1.942, p=.052)$.

\subsection{2. 시점 간 비유창성 빈도 비교}

각 집단에서 시점 간 $\mathrm{ND}$ 및 $\mathrm{AD}$ 빈도에 유의한 차이가 있는가
를 알아보기 위해 Wilcoxon Signed-Rank Test를 실시한 결과, 두 집단 모두 유의한 차이가 없는 것으로 나타났다(말더듬아동 집 단의 $\mathrm{ND}$ 빈도: $Z=-.318, p=.750$; 말더듬아동 집단의 $\mathrm{AD}$ 빈도: $Z=-.946, p=.344$; 일반아동 집단의 $\mathrm{ND}$ 빈도: $Z=-1.472, p=.141$; 일반아동 집단의 $\mathrm{AD}$ 빈도: $Z=.000, p=1.000$ ).

표 1. 집단 간 $\mathrm{ND}$ 및 $\mathrm{AD}$ 빈도 비교

Table 1. Comparisons of ND and $\mathrm{AD}$ frequency between children groups

\begin{tabular}{|c|c|c|c|c|}
\hline \multirow[t]{2}{*}{ 시점 } & \multirow[t]{2}{*}{ 비유창성 } & $\begin{array}{l}\text { CWS } \\
(n=6)\end{array}$ & $\begin{array}{c}\text { CWNS } \\
(n=6)\end{array}$ & \multirow[t]{2}{*}{$Z$-value } \\
\hline & & M (IQR) & M (IQR) & \\
\hline \multirow{2}{*}{$\begin{array}{l}\text { 평가 } \\
\text { 시점 }\end{array}$} & ND (회) & $\begin{array}{c}17.50 \\
(17.75)\end{array}$ & $\begin{array}{r}8.00 \\
(7.5)\end{array}$ & $-2.100^{*}$ \\
\hline & AD (회) & $\begin{array}{c}11.50 \\
(19.75)\end{array}$ & $\begin{array}{r}2.50 \\
(2.75)\end{array}$ & $-2.892^{*}$ \\
\hline \multirow{2}{*}{$\begin{array}{c}\text { 평가 후 } \\
12 \text { 개월 } \\
\text { 시점 }\end{array}$} & ND (회) & $\begin{array}{c}18.50 \\
(13.25)\end{array}$ & $\begin{array}{c}11.50 \\
(12.00)\end{array}$ & -1.363 \\
\hline & AD (회) & $\begin{array}{c}10.00 \\
(10.00)\end{array}$ & $\begin{array}{r}1.50 \\
(4.00) \\
\end{array}$ & -1.942 \\
\hline
\end{tabular}

${ }^{*} p<.05$.

$\mathrm{ND}$, normal disfluency; AD, abnormal disfluency; CWS, children who stutter; CWNS, children who do not stutter; M, median; IQR, interquartile range.

3.2. 아동의 끼어들기 빈도 및 끼어들기 시 동시에 말한 시간 각 시점(평가 시점, 평가 후 12 개월 시점)에서 말더듬아동 집 단과 일반아동 집단의 끼어들기 빈도 및 끼어들기 시 동시에 말 한 시간에 대해 비교한 결과는 표 2와 같다.

\subsection{1. 집단 간 끼어들기 빈도 및 끼어들기 시 동시에 말한 시간 비교}

각 시점에서 집단 간 끼어들기 빈도 및 끼어들기 시 동시에 말한 시간에 유의한 차이가 있는가를 알아보기 위해 MannWhitney U-Test를 실시한 결과, 통계적으로 유의한 차이가 없는 것으로 나타났다(평가 시점에서 끼어들기 빈도: $Z=-1.218$, $p=.223$; 평가 후 12 개월 시점에서 끼어들기 빈도: $Z=-1.963$, $p=.05$; 평가 시점에서 끼어들기 시 동시에 말한 시간: $Z=-1.444$, $p=.149$; 평가 후 12 개월 시점에서 끼어들기 시 동시에 말한 시 간: $Z=-.160, p=.873)$.

\subsection{2. 시점 간 끼어들기 빈도 및 끼어들기 시 동시에 말한 시간 비교}

각 집단에서 시점 간 끼어들기 빈도 및 끼어들기 시 동시에 말한 시간에 유의한 차이가 있는가를 알아보기 위해 Wilcoxon Signed-Rank Test를 실시한 결과, 말더듬아동 집단에서 끼어들기 빈도가 평가 시점보다 평가 후 12 개월 시점에서 유의하게 증가한 것으로 나타났다(말더듬아동 집단의 끼어들기 빈도: $Z=-2.041$, $p<.05)$.

반면, 일반아동 집단에서는 시점 간 끼어들기 빈도에 유의한 차이가 없는 것으로 나타났으며, 두 집단 모두 끼어들기 시 동 시에 말한 시간에 유의한 차이가 없는 것으로 나타났다(말더듬 
아동 집단의 끼어들기 시 동시에 말한 시간: $Z=-.314, p=.753$; 일반아동 집단의 끼어들기 빈도: $Z=-1.511, p=.131$; 일반아동 집단의 끼어들기 시 동시에 말한 시간: $Z=-1.572, p=.116$ ).

\section{표 2. 집단 간 아동의 끼어들기 빈도 및 끼어들기 시 동시에 말한 시간 비교}

Table 2. Comparisons of interruptions frequency and simultalk duration between children groups

\begin{tabular}{|c|c|c|c|c|}
\hline \multirow[t]{2}{*}{ 시점 } & \multirow{2}{*}{$\begin{array}{l}\text { 끼어들기 } \\
\text { 특성 }\end{array}$} & $\begin{array}{l}\text { CWS } \\
(\mathrm{n}=6)\end{array}$ & $\begin{array}{l}\text { CWNS } \\
(\mathrm{n}=6)\end{array}$ & \multirow[t]{2}{*}{$Z$-value } \\
\hline & & $\mathrm{M}(\mathrm{IQR})$ & $\mathrm{M}(\mathrm{IQR})$ & \\
\hline \multirow{2}{*}{$\begin{array}{l}\text { 평가 } \\
\text { 시점 }\end{array}$} & 끼어들기 빈도 (회) & $\begin{array}{c}1.50 \\
(3.50)\end{array}$ & $\begin{array}{c}2.50 \\
(4.75)\end{array}$ & -1.218 \\
\hline & $\begin{array}{c}\text { 끼어들기 시 동시에 } \\
\text { 말한 시간 (초) }\end{array}$ & $\begin{array}{l}1.13 \\
(1.4)\end{array}$ & $\begin{array}{c}1.40 \\
(0.30)\end{array}$ & 44 \\
\hline \multirow{2}{*}{$\begin{array}{c}\text { 평가 후 } \\
12 \text { 개월 } \\
\text { 시점 }\end{array}$} & 끼어들기 빈도 (회) & $\begin{array}{c}4.00 \\
(2.25)\end{array}$ & $\begin{array}{c}1.50 \\
(3.25)\end{array}$ & -1.963 \\
\hline & $\begin{array}{c}\text { 끼어들기 시 동시에 } \\
\text { 말한 시간 (초) }\end{array}$ & $\begin{array}{c}0.74 \\
(0.24)\end{array}$ & $\begin{array}{c}0.83 \\
(1.39)\end{array}$ & -.160 \\
\hline
\end{tabular}

CWS, children who stutter; CWNS, children who do not stutter; M, median; IQR, interquartile range.

3.3. 어머니의 끼어들기 빈도 및 끼어들기 시 동시에 말한 시간

각 시점(평가 시점, 평가 후 12 개월 시점)에서 말더듬아동 어 머니 집단과 일반아동 어머니 집단의 끼어들기 빈도 및 끼어들 기 시 동시에 말한 시간에 대해 비교한 결과는 표 3 과 같다.

\subsection{1. 집단 간 끼어들기 빈도 및 끼어들기 시 동시에 말한 시간 비교}

각 시점에서 집단 간 끼어들기 빈도 및 끼어들기 시 동시에 말한 시간에 유의한 차이가 있는가를 알아보기 위해 MannWhitney U-Test를 실시한 결과, 평가 시점에서 말더듬아동 어머 니 집단의 끼어들기 빈도가 일반아동 어머니 집단의 끼어들기 빈도보다 통계적으로 유의하게 낮은 것으로 나타났다(평가 시 점에서 끼어들기 빈도: $Z=-2.246, p<.05)$.

반면, 평가 후 12 개월 시점에서 두 집단 모두 유의한 차이가 없는 것으로 나타났다(평가 후 12 개월 시점에서 끼어들기 빈도: $Z=-.561, p=.589$; 평가 시점에서 끼어들기 시 동시에 말한 시간: $Z=-.962, p=.336$; 평가 후 12 개월 시점에서 끼어들기 시 동시에 말한 시간: $Z=-.561, p=.575)$.

\subsection{2. 시점 간 끼어들기 빈도 및 끼어들기 시 동시에 말한 시간 비교}

각 집단에서 시점 간 끼어들기 빈도 및 끼어들기 시 동시에 말한 시간에 유의한 차이가 있는가를 알아보기 위해 Wilcoxon Signed-Rank Test를 실시한 결과, 일반아동 어머니 집단에서 동 시에 말한 시간이 유의하게 감소한 것으로 나타났다(말더듬아 동 어머니 집단의 끼어들기 빈도: $Z=-1.214, p=.225$; 말더듬아 동 어머니 집단의 끼어들기 시 동시에 말한 시간: $Z=-.405$, $p=.686$; 일반아동 어머니 집단의 끼어들기 빈도: $Z=-.524$, $p=600$; 일반아동 어머니 집단의 끼어들기 시 동시에 말한 시간: $Z=-1.992, p<.05)$.

표 3. 집단 간 어머니의 끼어들기 빈도 및 끼어들기 시 동시에 말한 시간(sec) 비교

Table 3. Comparisons of interruptions frequency and simultalk duration between mothers groups

\begin{tabular}{|c|c|c|c|c|}
\hline \multirow[t]{2}{*}{ 시점 } & \multirow{2}{*}{$\begin{array}{c}\text { 끼어들기 } \\
\text { 특성 }\end{array}$} & $\begin{array}{l}\text { CWS } \\
(\mathrm{n}=6)\end{array}$ & $\begin{array}{c}\text { CWNS } \\
(\mathrm{n}=6)\end{array}$ & \multirow[t]{2}{*}{$Z$-value } \\
\hline & & M (IQR) & $\mathrm{M}(\mathrm{IQR})$ & \\
\hline \multirow{2}{*}{$\begin{array}{l}\text { 평가 } \\
\text { 시점 }\end{array}$} & 끼어들기 빈도 (회) & $\begin{array}{c}1.54 \\
(1.88)\end{array}$ & $\begin{array}{c}2.22 \\
(1.08) \\
\end{array}$ & $-2.246^{*}$ \\
\hline & $\begin{array}{c}\text { 끼어들기 시 동시에 } \\
\text { 말한 시간 (초) }\end{array}$ & $\begin{array}{c}0.88 \\
(1.86)\end{array}$ & $\begin{array}{c}1.32 \\
(0.43)\end{array}$ & -.962 \\
\hline \multirow{2}{*}{$\begin{array}{c}\text { 평가 후 } \\
12 \text { 개월 } \\
\text { 시점 }\end{array}$} & 끼어들기 빈도 (회) & $\begin{array}{c}1.81 \\
(4.62)\end{array}$ & $\begin{array}{c}3.14 \\
(1.88)\end{array}$ & -.561 \\
\hline & $\begin{array}{c}\text { 끼어들기 시 동시에 } \\
\text { 말한 시간 (초) }\end{array}$ & $\begin{array}{c}0.84 \\
(0.62) \\
\end{array}$ & $\begin{array}{c}1.02 \\
(0.71) \\
\end{array}$ & -.561 \\
\hline
\end{tabular}

CWS, children who stutter; CWNS, children who do not stutter; M, median; IQR, interquartile range; ND, normal disfluency.

3.4. 말더듬아동 및 어머니 요인과 아동의 비유창성 빈도 간 의 관계

평가 시점과 평가 후 12 개월 시점에 말더듬아동 집단의 비유 창성 $(\mathrm{ND}, \mathrm{AD})$ 빈도와 아동 요인(끼어들기 빈도, 끼어들기 시 동 시에 말한 시간), 어머니 요인(끼어들기 빈도, 끼어들기 시 동시 에 말한 시간) 간의 상관관계를 살펴보기 위해 스피어만 등위상 관분석을 실시하였다.

\subsection{1. 평가 시점의 상관 분석}

평가 시점의 말더듬아동 집단의 $\mathrm{ND}$ 및 $\mathrm{AD}$ 빈도와 아동 요인, 어머니 요인 간의 관계를 스피어만 등위상관분석한 결과는 부 록 2와 같다.

평가 시점의 말더듬아동 집단의 비유창성 빈도와 아동 요인, 어머니 요인 간의 관계를 살펴보기 위해 스피어만 등위상관분 석을 실시한 결과, 아동 비유창성 빈도와 유의한 상관관계를 보 인 요인은 없었다.

\subsection{2. 평가 후 12 개월 시점의 상관 분석}

평가 후 12 개월 시점의 말더듬아동 집단의 $\mathrm{ND}$ 및 $\mathrm{AD}$ 빈도와 아동 요인, 어머니 요인 간의 관계를 스피어만 등위상관분석한 결과는 부록 3 과 같다.

평가 후 12 개월 시점의 말더듬아동 집단의 비유창성 빈도와 아동 요인, 어머니 요인 간의 관계를 살펴보기 위해 스피어만 등위상관분석을 실시한 결과, 말더듬아동·어머니 집단에서 아 동 비유창성 빈도와 유의한 상관관계를 보인 요인은 없었다.

\section{4. 결론}

본 연구는 학령전 말더듬아동과 어머니의 자연스러운 상호 작용 상황에서 나타나는 끼어들기 빈도와 끼어들기 시 동시에 
말한 시간이 아동의 비유창성과 관련성이 있는지를 종단적으 로 분석하였다. 그리고 말더듬아동과 어머니의 상호작용 특성 을 일반아동 집단과 비교하였을 때 차이를 보이는가를 살펴보 았다.

연구 결과는 다음과 같다. 첫째, 평가 시점에서 말더듬아동 집단의 비유창성 빈도가 일반아동 집단의 비유창성 빈도보다 통계적으로 유의하게 높은 것으로 나타났고, 평가 후 12 개월 시 점에서는 통계적으로 유의한 차이가 없는 것으로 나타났다. 둘 째, 평가 시점과 평가 후 12 개월 시점에서 말더듬아동 집단과 일반아동 집단 간 끼어들기 빈도와 끼어들기 시 동시에 말한 시 간에 통계적으로 유의한 차이가 없는 것으로 나타났고, 말더듬 아동 집단에서 시점 간 끼어들기 빈도가 유의하게 증가한 것으 로 나타났다. 셋째, 평가 시점에서 말더듬아동 어머니 집단의 끼어들기 빈도가 일반아동 어머니 집단의 끼어들기 빈도보다 통계적으로 유의하게 낮은 것으로 나타났고, 평가 시점에서 끼 어들기 시 동시에 말한 시간, 평가 시점과 평가 후 12 개월 시점 에서 끼어들기 시 동시에 말한 시간에 통계적으로 유의한 차이 가 없는 것으로 나타났다. 넷째, 말더듬아동·어머니 집단에서 시점별(평가 시점, 평가 후 12 개월 시점) 아동의 비유창성 빈도 와 아동과 부모의 끼어들기 특성 간 상관관계를 살펴본 결과, 상관관계를 보인 요인은 없었다.

그 결과에 대한 논의는 다음과 같다.

첫째, 평가 시점에서 말더듬아동 집단의 $\mathrm{ND}$ 빈도와 $\mathrm{AD}$ 빈도 가 일반아동 집단의 $\mathrm{ND}$ 빈도와 $\mathrm{AD}$ 빈도보다 통계적으로 유의 하게 높은 것으로 나타났고, 평가 후 12 개월 시점에서는 통계적 으로 유의한 차이가 없는 것으로 나타났다. 이러한 결과는 각 시점에서 나타난 개별 말더듬아동의 $\mathrm{AD}$ 빈도 차이가 크고, 본 연구에서 참여한 말더듬아동 대부분이 치료를 받은 경험에서 비롯된 것으로 사료된다.

말더듬아동은 유창성을 저해하는 자극에 일반아동보다 더 많은 영향을 받으며, 그와 같은 취약성(vulnerability)으로 인해 비유창성 변화의 폭이 크게 나타나는데(Lee \& Sim, 2007; Min, 2007), 본 연구에 참여한 말더듬아동의 개별적 특성을 살펴보았 을 때, 평가 시점에서 가장 낮은 $\mathrm{AD}$ 빈도를 보인 아동은 7회를 보였으며, 가장 높은 $\mathrm{AD}$ 빈도를 보인 아동은 39회였다. 개별 아 동 내에서 시점 간 $\mathrm{AD}$ 빈도 차가 가장 큰 경우는 12 회였으며, 가 장 작은 경우는 1 회였다. 또한 본 연구에 참여한 말더듬아동 대 부분이 간접치료 또는 간접치료와 직접치료를 모두 받은 경험 이 있으므로 연구 결과에 영향을 미쳤을 것으로 판단된다. 추후 연구에서는 말더듬아동을 집단뿐만 아니라 개별로 살펴보고, 대상자들의 중재 기간과 중재 방법을 통제하여 살펴본다면 근 거를 더욱 명확히 할 수 있을 것으로 보인다.

둘째, 평가 시점과 평가 후 12 개월 시점에서 말더듬아동 집 단과 일반아동 집단 간 끼어들기 빈도와 끼어들기 시 동시에 말 한 시간에 통계적으로 유의한 차이가 없는 것으로 나타났다. 이 러한 결과는 평가 시점과 평가 후 6개월 시점에서 끼어들기 빈 도를 분석한 선행연구와 일치하는 결과이다(Kwak et al., 2020). 대화 상황에서는 대화 상대방의 대화차례 빈도, 길이 및 내용을
정확하게 예측하기 어렵기 때문에(Sacks et al., 1974) 상대방에 의해 나타나는 많은 변수들을 빠르게 조절할 수 있는 대화차례 관리 기술이 요구된다. 이러한 기술이 약 3-4세에 발달한다는 점을 고려하였을 때(Garvey \& Berninger, 1981; Kelly \& Conture, 1992), 본 연구 결과는 아동이 자신의 대화차례를 인식하고 상 대방과 원활하게 대화차례를 주고 받는 기술 즉, 화용적인 측면 에 있어서 말더듬아동과 일반아동 간 차이가 없음을 의미한다.

또한, 말더듬아동 집단에서 시점 간 끼어들기 빈도가 유의하 게 증가한 것으로 나타났다. 이러한 결과는 말더듬아동들이 의 사소통 상황에서 본인의 의견을 적극적으로 표현하는 과정에 서 더 잦은 끼어들기를 보인 것으로 추측해볼 수 있다. 학령전 말더듬아동들도 본인의 비유창성을 인식하고 있기 때문에 말 하기에 대해 부정적인 태도를 가지고 대화 상황에서 소극적인 경향을 보인다(Park et al., 2015; Vanryckeghem \& Brutten, 2002). 이러한 대상자의 인식과 감정 상태는 말더듬 중재방법을 결정 하고 치료계획을 수립할 때 중요한 근거가 될 정도로 중요하다 (Lee, 2003). 본 연구에 참여한 말더듬아동 대부분이 간접치료 또는 간접치료와 직접치료를 받은 점을 고려하면 말하기에 대 한 부정적인 태도가 긍정적으로 변했을 수 있으며, 이에 의사소 통 상황에 적극적으로 참여하면서 끼어들기 빈도가 증가한 가 능성이 있을 것으로 보인다.

또한 말더듬아동 집단에서 시점 간 비유창성 빈도에 차이가 없는 것으로 나타났고, 12 개월 시점의 데이터를 기반으로 하여 회복집단과 지속집단으로 구분하지 않았으나 말더듬에서 회복 되는 아동들은 의사소통 상황에서 더 적극적이고 자기주장적 일 가능성이 있으며, 말더듬이 지속되는 아동들은 여전히 소극 적이고 반응적일 가능성이 있다고 본다(Yairi \& Ambrose, 2005). 추후 연구에서는 말더듬아동 집단을 회복집단과 지속집단으로 구분하여 끼어들기 행동뿐만 아니라 의사소통 행동도 함께 분 석할 필요가 있다.

셋째, 평가 시점에서 말더듬아동 어머니 집단의 끼어들기 빈 도가 일반아동 어머니 집단의 끼어들기 빈도보다 통계적으로 유의하게 낮은 것으로 나타났고, 평가 시점에서 끼어들기 시 동 시에 말한 시간, 평가 후 12 개월 시점에서는 통계적으로 유의한 차이가 없는 것으로 나타났다. 이는 말더듬아동 부모가 일반아 동 부모와 다른 방식으로 의사소통하고, 말더듬아동 부모가 일 반아동 부모보다 유의하게 끼어들기를 보였다고 한 선행연구와 는 일치하지 않는 결과이다(Allan \& Williams, 1974; Egolf et al., 1972; Kasprisin-Burrelli et al., 1972; Mordecai, 1979). Mordecai (1979)는 말더듬아동 부모가 일반아동 부모보다 유의하게 높은 끼어들기 빈도를 보였으며 연구자들은 이러한 결과를 아동의 의사소통 노력에 대한 부모의 관심이 부족하여 아동의 발화를 방해하는 부정적인 상호작용의 증거로 해석하였다. 반면 본 연 구에서는 평가 시점에서 오히려 말더듬아동 어머니 집단의 끼 어들기 빈도가 일반아동 어머니 집단의 끼어들기 빈도보다 통 계적으로 유의하게 낮은 것으로 나타났으며, 평가 후 12 개월 시 점에서는 통계적으로 유의한 차이가 없는 것으로 나타났다. 이 러한 결과는 간접치료 효과 유지 여부에서 비롯된 것으로 추측 
해볼 수 있다. 본 연구에 참여한 말더듬아동과 말더듬아동 어머 니들은 대부분 간접치료를 받았는데, 평가 시점에는 간접치료 를 받은 지 얼마 지나지 않았으므로 끼어들기 빈도가 낮게 나타 나는 치료 효과가 나타났고, 12 개월이 지난 시점에서는 치료 효 과가 유지되지 않았을 가능성이 있다. $\operatorname{Ramig}(1993)$ 는 아동 중재 에 부모가 적극적으로 개입하지 않으면 중재 효과의 전이와 유 지에 어려움뿐만 아니라, 중재가 종료되고 난 후에도 급속도로 아동의 말더듬이 재발될 수 있다고 하였다. 본 연구 결과는 간 접치료가 종결되거나 간접치료에서 직접치료로 전환하더라도 간접치료 효과가 아동과의 상호작용 상황에서 지속될 수 있도 록 모니터링의 중요함을 강조하여 임상적 의의가 높다.

넷째, 말더듬아동·어머니 집단에서 시점별(평가 시점, 평가 후 12 개월 시점) 아동의 비유창성 빈도와 아동과 부모의 끼어들 기 특성 간 상관관계를 살펴본 결과, 상관관계를 보인 요인은 없었다. 특히, 본 연구는 횡단이 아닌 1년이라는 간격을 두어 종 단적으로 아동의 비유창성과 아동과 부모의 끼어들기 행동을 분석하였음에도 유의한 상관관계를 보이는 종속 변인이 없었 다. 이러한 결과는 아동 및 부모의 끼어들기 특성과 아동의 비 유창성 간의 유의한 상관관계가 나타나지 않았다고 한 선행연 구와 일치하며(Kelly \& Conture, 1992; Kwak et al., 2020), 끼어들 기 행동 이외에 아동의 비유창성과 관련이 있는 것으로 알려진 다른 요인들도 함께 살펴볼 필요가 있고, 끼어들기 행동을 말더 듬아동의 유창성을 저해하는 말더듬아동 부모의 대표적인 특 성으로 간주하는 것에 한계가 있음을 의미한다. 따라서 말더듬 아동의 간접치료의 측면에서 모든 말더듬아동의 부모에게 일 률적으로 끼어들기 행동의 감소를 제언하기보다는 각 아동과 부모가 보이는 상호작용 방식을 다방면으로 관찰하여 이에 적 절한 제언이 필요함을 시사하는 바이다.

본 연구의 제한점은 연구대상자 수가 각 집단별 6 쌍으로 적 은 수이고, 모든 대상자의 치료여부 및 중재 기간과 중재 방법 을 동일하게 통제하지 못한 것에 있다. 또한 성별과 말더듬 지 속기간(말더듬아동 대부분은 말더듬 시작 시점부터 평가 시점 까지의 기간이 1 년 이내였으나 CWS5의 경우, 1 년을 초과하였 음.)과 같은 대상자의 배경 변인을 통제하지 못하였다. 이에 후 속 연구에서는 (1) 더 많은 대상자 수 확보 (2) 배경 변인(성별, 말더듬 지속기간, 중재 기간, 중재 방법 등)을 통제하여 종속 변 인 분석 (3) 집단 뿐만 아니라 개별 아동 - 부모 분석 (4) 말더듬 아동 집단을 회복집단과 지속집단으로 분류하여 분석한다면 더 유의하고, 일관적인 연구 결과를 산출하는데 도움이 될 것으 로 기대한다.

\section{References}

Allan, F. E., \& Williams, C. L. (1974). Interaction patterns of families containing a stuttering sibling. Australian Journal of Human Communication Disorders, 2(1), 32-40.

Ambrose, N. G., \& Yairi, E. (1999). Normative disfluency data for early childhood stuttering. Journal of Speech, Language, and
Hearing Research, 42(4), 895-909.

Boersma, P., \& Weenink, D. (2012). Praat: Doing phonetics by computer (version 5.3.16) [Computer program]. Retreived from http://www.praat.org

Conture, E. G. (1990). Stuttering (2nd ed.). Englewood Cliffs, NJ: Prentice-Hall.

Craig, C. (2013). Goldwave (version 5.70) [Computer software]. St. John's, NF: Goldwave.

Egolf, D. B., Shames, G. H., Johnson, P. R., \& Kasprisin-Burrelli, A. (1972). The use of parent-child interaction patterns in therapy for young stutterers. Journal of Speech and Hearing Disorders, 37(2), 222-232.

Garvey, C., \& Berninger, G. (1981). Timing and turn taking in children's conversations. Discourse Processes, 4(1), 27-57.

Heo, H., \& Lee, Y. K. (2012). Conversational turn-taking and topic manipulation skills in conversations of school-age low-achievers in language learning. Communication Sciences \& Disorders, 17(1), 66-78.

Kasprisin-Burrelli, A., Egolf, D. B., \& Shames, G. H. (1972). A comparison of parental verbal behavior with stuttering and nonstuttering children. Journal of Communication Disorders, 5(4), 335-346.

Kelly, E. M. (1993). Speech rates and turn-taking behaviors of children who stutter and their parents. Seminars in Speech and Language, 14(3), 203-214.

Kelly, E. M., \& Conture, E. G. (1992). Speaking rates, response time latencies, and interrupting behaviors of young stutterers, nonstutterers, and their mothers. Journal of Speech, Language, and Hearing Research, 35(6), 1256-1267.

Kim, Y. T., \& Shin, M. J. (2004). Urimal test of articulation and phonology (U-TAP). Seoul, Korea: Hakjisa.

Kim, Y., Hong, G., Kim, K., Jang, H., \& Lee, J. (2009). Receptive \& Expressive Vocabulary Test (REVT). Seoul, Korea: Seoul Community Rehabilitation Center.

Kwak, H. J., Sim H. S., \& Lee, S. B. (2021). A longitudinal analysis on the duration of utterance in a conversational turn and turn-switching pause in preschool children who stutter during interactions with their mothers. Communication Sciences \& Disorders, 26(3), 700-717.

Kwak, H., Hwang, S., Song, P., Kim, H., Lee, S., \& Sim, H. (2020, November). A longitudinal study on the interruption in preschool children who stuttering and parent interactions. Proceedings of the 2020 online Conferences on The Korean Academy of SpeechLanguage Pathology and Audiology (pp. 301-304).

Lee, E. J. (2003). Children who stutter assessment and practice. Paper presented at the Workshop for the 6th International Stuttering Awareness Day.

Lee, E., \& Sim, H. S. (2007). Temperament of preschool children who 
stutter and mother's temperament and parenting style. Korean Journal of Communication \& Disorders, 12(2), 279-295.

Lee, S. B., \& Sim, H. S. (2016). Fluency predictor variables in early stuttering intervention for children. Communication Sciences \& Disorders, 21(2), 382-396.

Lee, S. B., Lee, D. Y., Sim, H. S., \& Yim, D. S. (2019). The potential usage of language skills for predicting recovery from persistent group in Korean speaking children who stutter. Communication Sciences \& Disorders, 24(1), 141-153.

Lee, S., \& Sim, H. S. (2015). A longitudinal study of utterance length in morphemes as a predictor of treatment outcome in early childhood stuttering. Communication Sciences \& Disorders, 20(2), 189-201.

Livingston, L. A., Flowers, Y. E., Hodor, B. A., \& Ryan, B. P. (2000). The experimental analysis of interruption during conversation for three children who stutter. Journal of Developmental and Physical Disabilities, 12(4), 235-266.

Meyers, S. C., \& Freeman, F. J. (1985). Interruptions as a variable in stuttering and disfluency. Journal of Speech, Language, and Hearing Research, 28(3), 428-435.

Min, K. (2007). Variability in the frequency of disfluenices produced by stuttering and nonstuttering children in three speaking tasks (Master's thesis). Ewha Womans University, Seoul, Korea.

Mordecai, D. R. (1979). An investigation of the communicative styles of mothers and fathers of stuttering versus nonstuttering preschool children during a triadic interaction (Doctoral dissertation). Northwestern University, Evanston, IL.

Park, H. Y., Lee, S. B., \& Sim, H. S. (2015). Communication behaviors of stuttering recovery and stuttering persistent groups. Journal of Speech-Language \& Hearing Disorders, 24(4), 237-248.

Park, Y. R., \& Choi, S. Y. (2019). The effects of conversational skills intervention through group program on conversational turn-taking and topic manipulation skills of school-age children with language delay. Journal of Speech-Language \& Hearing Disorders, 28(2), 115-128.

Ramig, P. R. (1993). Parent-clinician-child partnership in the therapeutic process of the preschool-and elementary-aged child who stutters. Seminars in Speech and Language, 14, 226-237.

Riley, G. D. (1980). Stuttering severity instrument. Tigard, OR: C. C. Publications.

Sacks, H., Schegloff, E. A., \& Jefferson, G. (1974). A simplest systematics for the organization of turn-taking for conversation. Language, 50(4), 696-735.

Savelkoul, E. M., Zebrowski, P. M., Feldstein, S., \& Cole-Harding, S. (2007). Coordinated interpersonal timing in the conversations of children who stutter and their mothers and fathers. Journal of Fluency Disorders, 32(1), 1-32.

Sim, H., Shin, M., \& Lee, E. (2010). Paradise-fluency assessment (2nd ed.). Seoul, Korea: Paradise Welfare Foundation.

Smith, A., \& Kelly, E. M. (1997). Stuttering: A dynamic, multifactorial model. In G. M. Siegel, \& R. F. Curlee (Eds.), Nature and treatment of stuttering: New directions (2nd ed., pp. 204-217). Boston, MA: Allyn \& Bacon.

Starkweather, C. W., \& Gottwald, S. R. (1990). The demands and capacities model II: Clinical applications. Journal of Fluency Disorders, 15(3), 143-157.

Van Riper, C. (1982). The nature of stuttering (2nd ed.). Englewood Cliffs, NJ: Prentice-Hall.

Vanryckeghem, M., \& Brutten, G. (2002). KiddyCAT: A measure of stuttering and nonstuttering preschoolders' attitude. ASHA Leader, 7(15), 104

Weiss, A. (2004). Why we should consider pragmatics when planning treatment for children who stutter. Language, Speech, and Hearing Services in Schools, 35(1), 34-45.

Weiss, A. L. (1995). Conversational demands and their effects on fluency and stuttering. Topics in Language Disorders, 15(3), 18-31.

Yairi, E., \& Ambrose, N. G. (2005). Early childhood stuttering. Austin: PRO-ED.

Zebrowski, P. M. (1995). Temporal aspects of the conversations between children who stutter and their parents. Topics in Language Disorders, 15(3), 1-17.

Zebrowski, P. M., \& Kelly, E. M. (2002). Manual of stuttering intervention. Clifton Park, NY: Thomson Delmas Learning.

Zebrowski, P. M., Weiss, A. L., Savelkoul, E. M., \& Hammer, C. S. (1996). The effect of maternal rate reduction on the stuttering, speech rates and linguistic productions of children who stutter: Evidence from individual dyads. Clinical linguistics \& phonetics, 10(3), 189-206.

\section{- 곽효정 (Hyojung Kwak)}

이화여자대학교 언어병리학과 석사 서울특별시 서대문구 이화여대길 52

Tel: 02-3277-2120

Email: yd61581@naver.com

관심분야: 의사소통장애

\section{- 황시현 (Sihyeon Hwang)}

이화여자대학교 언어병리학과 석사

서울특별시 서대문구 이화여대길 52

Tel: 02-3277-2120

Email: tlgus7894@hanmail.net

관심분야: 의사소통장애 


\section{- 송푸름 (Pureum Song)}

우송대학교 언어치료청각재활학과 학사과정

대전광역시 동구 동대전로 171

Tel: 042-630-9220

Email: intprelude@naver.com

관심분야: 유창성장애, 언어발달장애

\section{- 심현섭 (Hyunsub Sim)}

이화여자대학교 언어병리학과 교수

서울특별시 서대문구 이화여대길 52

Tel: 02-3277-2120

Email:simhs@ewha.ac.kr

관심분야: 유창성장애, 음성장애

- 이수복 (Soobok Lee) 교신저자

우송대학교 언어치료청각재활학과 교수

대전광역시 동구 동대전로 171

Tel: 042-630-9220

Email: sblee@wsu.ac.kr

관심분야: 유창성장애, 종단연구, IT융합 
부록 1. 연구 참여 아동 정보

\begin{tabular}{|c|c|c|c|c|c|c|c|}
\hline Group & Case no. & Gender & Age at initial visit & Age at onset & $\begin{array}{c}\text { Duration of } \\
\text { treatment }\end{array}$ & $\begin{array}{c}\text { Treatment type at } \\
\text { initial visit }\end{array}$ & $\begin{array}{c}\text { Stuttering severity } \\
\text { at initial visit }\end{array}$ \\
\hline \multirow{6}{*}{$\begin{array}{l}\text { CWS } \\
(n=6)\end{array}$} & CWS1 & $\mathrm{F}$ & $2 ; 1$ & $1 ; 10$ & 3 months & Indirect & Not rated \\
\hline & CWS2 & $\mathrm{F}$ & $2 ; 10$ & $1 ; 11$ & 3 months & Indirect & Moderate \\
\hline & CWS3 & $\mathrm{F}$ & $3 ; 4$ & $2 ; 5$ & 12 months & Indirect, Direct & Moderate \\
\hline & CWS4 & $\mathrm{M}$ & $3 ; 9$ & $3 ; 5$ & 12 months & Indirect, Direct & Moderate \\
\hline & CWS5 & $\mathrm{M}$ & $4 ; 9$ & $3 ; 3$ & 3 months & Indirect & Moderate \\
\hline & CWS6 & $\mathrm{F}$ & $5 ; 7$ & $5 ; 0$ & No & No & Mild \\
\hline \multirow{6}{*}{$\begin{array}{l}\text { CWNS } \\
(n=6)\end{array}$} & CWNS1 & M & $2 ; 3$ & - & - & - & Less than mild \\
\hline & CWNS2 & $\mathrm{F}$ & $2 ; 7$ & - & - & - & Less than mild \\
\hline & CWNS3 & M & $3 ; 11$ & - & - & - & Less than mild \\
\hline & CWNS4 & $\mathrm{M}$ & $4 ; 10$ & - & - & - & Less than mild \\
\hline & CWNS5 & $\mathrm{F}$ & $4 ; 11$ & - & - & - & Less than mild \\
\hline & CWNS6 & $\mathrm{F}$ & $5 ; 4$ & - & - & - & Less than mild \\
\hline
\end{tabular}

CWS, children who stutter; CWNS, children who do not stutter.

\section{부록 2. 평가 시점의 요인 간 상관관계 분석}

\begin{tabular}{c|c|c|c}
\hline Interruption & Group & ND & AD \\
\hline $\begin{array}{c}\text { Children's } \\
\text { frequency }\end{array}$ & CWS (n=6) & -0.087 & 0.721 \\
\hline $\begin{array}{c}\text { Children's } \\
\text { simultalk duration }\end{array}$ & CWS (n=6) & -0.319 & 0.456 \\
\hline $\begin{array}{c}\text { Mother's } \\
\text { frequency }\end{array}$ & CWS (n=6) & 0.555 & -0.329 \\
\hline $\begin{array}{c}\text { Mother's } \\
\text { simultalk duration }\end{array}$ & CWS (n=6) & 0.754 & 0.015 \\
\hline
\end{tabular}

ND, normal disfluency; AD, abnormal disfluency; CWS, children who stutter.
부록 3. 평가 후 12 개월 시점의 요인 간 상관관계 분석

\begin{tabular}{c|c|c|c}
\hline Interruption & Group & ND & AD \\
\hline $\begin{array}{c}\text { Children's } \\
\text { frequency }\end{array}$ & CWS (n=6) & -0.559 & 0.621 \\
\hline $\begin{array}{c}\text { Children's } \\
\text { simultalk duration }\end{array}$ & CWS (n=6) & -0.200 & 0.736 \\
\hline $\begin{array}{c}\text { Mother's } \\
\text { frequency }\end{array}$ & CWS (n=6) & 0.638 & -0.719 \\
\hline $\begin{array}{c}\text { Mother's } \\
\text { simultalk duration }\end{array}$ & CWS (n=6) & 0.029 & 0.294 \\
\hline
\end{tabular}

ND, normal disfluency; $\mathrm{AD}$, abnormal disfluency; CWS, children who stutter. 


\title{
학령전 말더듬아동과 어머니 간 상호작용 시 끼어들기 특성 종단적 분석*
}

\author{
곽 효 정' \\ ${ }^{1}$ 이화여자대학교 언어병리학과, ${ }^{2}$ 우송대학교 언어치료청각재활학과
}

\begin{abstract}
국문초록
본 연구는 학령전 말더듬아동과 어머니의 자연스러운 상호작용에서 나타나는 아동과 어머니의 끼어들기 특성을 분석하고 아동의 비유창성과의 관련성을 종단적으로 살펴보고자 하였다. 연구대상은 만 $2-5$ 세 말더듬아동과 어 머니 6쌍, 일반아동과 어머니 6쌍을 대상으로 하였다. 자연스러운 상호작용 상황에서 나타난 발화를 총 두 차례(평 가 시점, 평가 후 12 개월 시점) 수집하여 아동의 $\mathrm{ND}$ (normal disfluency) 빈도와 $\mathrm{AD}$ (abnormal disfluency) 빈도, 아동과 어머니의 끼어들기 빈도 및 끼어들기 시 동시에 말한 시간을 분석하였다. 연구 결과, (1) 평가시점에 말더듬아동 집 단과 일반아동 집단 간에 비유창성 빈도에서 유의한 차이를 보였다. (2) 평가 시점과 평가 후 12 개월 시점에 말더듬 아동 집단과 일반아동 집단 간의 끼어들기 빈도와 끼어들기 시 동시에 말한 시간에 유의한 차이가 없었다. 그러나 말더듬아동 집단은 평가 시점보다 평가 후 12 개월 시점에 끼어들기 빈도가 유의하게 증가하였다. (3) 평가 시점에 말더듬아동 어머니 집단과 일반아동 어머니 집단 간 끼어들기 빈도에서 유의한 차이가 나타났으나 끼어들기 시 동 시에 말한 시간에 유의한 차이가 없었다. (4) 말더듬아동 - 어머니 집단에서 시점별(평가 시점, 평가 후 12 개월 시 점) 아동의 비유창성 빈도와 아동과 부모의 끼어들기 특성 간 상관관계를 살펴본 결과, 평가 시점과 평가 후 12 개월 시점에서 아동의 $\mathrm{ND}$ 및 $\mathrm{AD}$ 빈도와 상관관계를 보인 요인은 없었다. 이러한 결과는 아동과 부모의 상호작용 시 나 타나는 끼어들기 특성을 대화 상대방의 발화를 방해하는 부정적인 상호작용의 증거로 해석하여 말더듬아동 - 부 모 상호작용 치료 시 끼어들기 행동에 대한 조언이 적절한지에 대해 고려해볼 필요가 있음을 시사한다.
\end{abstract}

핵심어: 학령전아동, 말더듬, 종단연구, 상호작용, 끼어들기, 끼어들기 시 동시에 말한 시간

\section{참고문헌}

고지민 (2013). 어머니와 만 2세 영아의 반응성 및 반응성간의 관계. 육아지원연구, 8(1), 241-267.

김영태 (2014). 아동언어장애의 진단 및 치료(제2판). 서울: 학 지사.

김영태, 홍경훈, 김경희, 장혜성, 이주연 (2009). 수용·표현어휘 력검사(REVT). 서울: 서울장애인종합복지관.

곽효정, 심현섭, 이수복 (2021). 학령전 말더듬아동과 아동의 어 머니 간 상호작용 종단적 분석: 대화차례 발화 시간과 쉼 시간 을 중심으로. 언어청각장애연구, 26(3), 700-717.

곽효정, 황시현, 송푸름, 김혜조, 이수복, 심현섭 (2020). 학령전 말더듬아동-부모 상호작용 시, 발화 끼어들기(interruption) 특 성에 관한 종단연구. 2020 한국언어청각임상학회 학술대회 발표논문집(pp. 301-304).

민경주 (2007). 과제에 따른 취학전 말더듬 아동과 일반 아동 의 비유창성 가변성 비교. 이화여자대학교 석사학위논문.
박영롱, 최소영 (2019). 그룹프로그램을 통한 대화기술 중재가 학 령기 언어발달지체 아동의 대화차례 주고받기 및 주제운용 능 력에 미치는 효과. 언어치료연구, 28(2), 115-128.

박혜연, 이수복, 심현섭 (2015). 취학 전 말더듬아동의 회복여부 에 따른 의사소통행동 특성. 언어치료연구, 24(4), 237-248.

심현섭, 신문자, 이은주 (2010). 파라다이스-유창성검사 II(P-FA II). 서울: 파라다이스 복지재단.

이수복, 심현섭 (2015). 초기 말더듬 아동의 치료후 말더듬회복 예측요인에 관한 종단연구: 발화길이를 중심으로. 언어청각 장애연구, 20(2), 189-201.

이수복, 심현섭 (2016). 초기 말더듬아동의 치료효과 예측변인 연 구. 언어청각장애연구, 21(2), 382-396.

이수복, 이다연, 심현섭, 임동선 (2019). 말더듬 회복 여부에 따른 초기 말더듬아동의 언어능력. 언어청각장애연구, 24(1), 141-153.

이은주 (2003). 말더듬 아동 평가 및 연습. 제6회 세계말더듬의 날 행사 유인물.

\footnotetext{
* 이 논문은 2018년 대한민국 교육부와 한국연구재단의 지원을 받아 수행된 연구임(NRF-2018S1A5A2A03036976).
} 
이은주, 심현섭 (2007). 취학전 말더듬아동의 기질과 어머니의 기 질 및 양육행동 특성. 언어청각장애연구, 12(2), 279-295.

전희정, 이수복 (2016). 취학 전 말더듬 아동의 말더듬 중증도에 따른 발화 형태 별 조음속도 비교. 말소리와 음성과학, 8(3), 79-90.

허현숙, 이윤경 (2012). 언어학습부진아동의 대화차례 주고받기 및 주제운용 특성. 언어청각장애연구, $17(1), 66-78$. 